\title{
In situ and laboratory bioassays using Poecilia reticulata Peters, 1859 in the biomonitoring of an acidic lake at Camaçari, BA, Brazil
}

\author{
Cristiano V.M. Araújo *, Salomão J. Cohin-de-Pinho, Jéssica da S. Santos, Flávia Delgado, \\ Lúcia C.S. Santana, Carla B.A. Chastinet, Eduardo M. da Silva \\ Instituto de Biologia, Federal University of Bahia, Campus de Ondina, 40170-115 Salvador, BA, Brazil
}

Received 14 October 2005; received in revised form 28 January 2006; accepted 4 February 2006

Available online 20 March 2006

\begin{abstract}
The suitability and viability of acute in situ bioassays were investigated in the biomonitoring program of an acidic lake contaminated with sulphur residues. Responses of organisms observed in laboratory and in situ bioassays were also assessed to determine whether or not they were similar and comparable, regarding accuracy and precision. Newborn Poecilia reticulata were employed as test organisms and exposed to the same water samples under in situ and laboratory conditions. Mortality/immobility was the endpoint assessed and dead/immobile organisms were counted at various time intervals during exposure. The mean calculated $\mathrm{LT}_{50}$ values and $95 \%$ confidence intervals were $1.61(1.36-1.87) \mathrm{h}$ in the laboratory bioassays and $0.72(0.55-0.89) \mathrm{h}$ in the in situ bioassays. Statistical comparison of these values revealed a significant difference $(p<0.05)$. In situ bioassays were more accurate than those carried out in the laboratory, demonstrating higher sensitivity and better reproduction of what occurs in nature, while laboratory bioassays were more precise.
\end{abstract}

(C) 2006 Elsevier Ltd. All rights reserved.

Keywords: Acidification; Acute toxicity; Dunas Lake; Lethal time

\section{Introduction}

Ecotoxicological laboratory bioassays employed to detect the acute or chronic effects of substances on the organisms (Boluda et al., 2002), have become increasingly important in risk assessment studies in terrestrial and aquatic environments (Kapanen and Itävaara, 2001). The important question is not if a chemical residue is in the environment, but whether the residue is having a significant effect on the environment (Wiersma et al., 1980).

Despite the efficiency of laboratory bioassays in demonstrating toxicity, and their consequent importance in environmental management, they may in some cases lack ecological relevance, because they are generally performed

\footnotetext{
* Corresponding author. Tel.: +55 713263 6525; fax: +55 7132636511. E-mail address: cvmaraujo@yahoo.com.br (C.V.M. Araújo).
}

under controlled conditions and do not simulate conditions in the field (Castro et al., 2003; Moreira-Santos et al., 2004). This reduces their predictive value and their applicability for extrapolation to natural ecosystems (Persoone et al., 1989). According to Pereira et al. (2000), laboratory exposure represents unrealistic conditions, therefore possibly underestimating real toxicity.

Uncertainties in the extrapolation of the laboratory data to natural ecosystems will always exist, because many physical, chemical and biological factors are integrated in the aquatic environment, being very difficult to replicate (Chappie and Burton, 2000; Pereira et al., 2000). Persoone et al. (1989) and Lewis et al. (1993) pointed out that laboratory toxicity data can be either under- or overestimates because standard laboratory conditions are very different from natural conditions. Some factors such as sample collection, storage or handling can also alter the sample characteristics and resultant toxicity (Castro et al., 2003). Some 
factors, such as the transport and handling of the test organism and uncontrolled environmental conditions, make it difficult to establish an exclusive cause for toxicity in in situ bioassays (USEPA, 2001).

On the other hand, in situ bioassays are a means for investigating the problem of ecological relevance (Moreira-Santos et al., 2004), thus reducing the uncertainties associated with laboratory bioassays (Chappie and Burton, 2000). They represent a link between laboratory bioassays and environment reality (Schulz and Liess, 1999). This association can be a valuable tool for understanding and predicting impacts on natural communities (Smolders et al., 2004), especially if site-specific ecotoxicological information is required (Castro et al., 2003).

Acidification studies in tropical waters are rare, although the effects on biological communities of lowering $\mathrm{pH}$ are similar to temperate waters (Jesus, 1996). This study aimed to investigate the adequacy and utility of acute in situ bioassays with Poecilia reticulata in the biomonitoring of an acidic lake, as well as to assess whether the responses, accuracy and precision of in situ bioassays were similar to those under laboratory conditions.

\section{Materials and methods}

\subsection{Study site}

The acidic lake (Dunas Lake) is located in Camaçari (BA, Brazil) between geographic coordinates $12^{\circ} 48^{\prime} 09^{\prime \prime}$ to $12^{\circ} 48^{\prime} 12.3^{\prime \prime} \mathrm{S}$ and $38^{\circ} 13^{\prime} 09^{\prime \prime}$ to $38^{\circ} 13^{\prime} 14^{\prime \prime} \mathrm{W}$. It lies within a depression, forming a narrow shallow body of freshwater between dunes along the South Atlantic Coast (da Silva et al., 2000).

According to da Silva et al. (2000), in the late 1980s large quantities (ca. $34 \mathrm{t}$ ) of both industrial and domestic solid waste including sulphur, iron, titanium dioxide and ilmenite residues were deposited on the adjacent dunes near the lake. These wastes were leached by rainwater percolating through the dunes, thus contaminating the ground- and surface-waters. There was a decrease to $\mathrm{pH} 1.8$ of groundand surface-water and an increase in the concentrations of dissolved iron and sulphate, causing the precipitation of humic acids and leading to highly transparent waters with a concurrent disruption of the biological communities in the lake (da Silva et al., 1999a, 2000).

A rehabilitation program was carried out (1992-1993) to recover groundwater and surface water quality and reduce contamination (Gomes, 1994; da Silva et al., 1999a). Initially, the residues were partially removed and the contaminated dune was sealed with impermeable layers of clay and topsoil (hydraulically encapsulated). An additional action was to pump groundwater to reduce the contaminated plume (Gomes, 1994; da Silva et al., 1999a, 2000). After this plan was put into practice a biomonitoring program, including bioassays with Poecilia reticulata, was established to assess the rehabilitation process of the Dunas Lake (da Silva et al., 1999b).

\subsection{Sampling}

Monthly samplings $(n=14)$ of the Dunas Lake were carried out from July 2003 to September 2004, except for August 2004. Samples were transported to the laboratory and kept at $4.0 \pm 1.0^{\circ} \mathrm{C}$ until the next day.

\subsection{Physical-chemical analysis}

Dissolved oxygen content, water hardness (APHA, 1998), pH (Digi-Sense, Cole Parmer) and conductivity (Hanna HI 9033) of the samples were evaluated at the beginning and end of each experiment. Mean $\mathrm{pH}$ was computed by calculating the average concentration of hydrogen ions and then calculating the respective $\mathrm{pH}$. Bioassay results were validated when $\mathrm{pH}$ variation was no higher than $10 \%$ of the initial $\mathrm{pH}$ value (Ribeiro et al., 2000).

\subsection{Test organism and acclimation}

$P$. reticulata neonates, $10-15$ days old (average length of $1.0 \pm 0.2 \mathrm{~cm}$ ), were obtained from a local aquarist who kept the fish under standardized conditions. In spite of the recommendation by OECD (1992) and ABNT (2002) to use adult $P$. reticulata in acute and static bioassays, neonates in early life stages were employed because they are more sensitive (Farag et al., 1993; Petersen and Kristensen, 1998), especially under rapid $\mathrm{pH}$ changes (Esteves, 1998).

The organisms were transported to the laboratory in glass flasks with sufficient air, and acclimated in 201 glass aquaria of dechlorinated tap water for at least $24 \mathrm{~h}$ prior to the experiments. The fish were not fed during this period or during the experiment. Acclimation and bioassays were performed at $26.0 \pm 1.0^{\circ} \mathrm{C}$, in constant temperature rooms with a photoperiod of 12:12 h (light and dark). Static acute toxicity tests were carried out according to OECD (1992) and ABNT (2002). Dechlorinated tap water, in which the fish had been reared, was used as a control.

\subsection{Laboratory bioassays}

Glass aquaria of 1.21 capacity, containing $900-1000 \mathrm{ml}$ of sample water, were used as test vessels. Five replicates of eight to ten fish each were tested, totalling 40-50 organisms exposed to each sample. The organisms were randomly distributed in the test vessels and fish mortality was checked every $10 \mathrm{~min}$. Time was the independent variable, and samples were not diluted. Dead fish were counted and removed immediately to avoid adverse effects due to decomposition of the organisms. Behavioural changes such as loss of equilibrium and swimming disorders were recorded. Organisms were only considered dead when operculum and gill movements had ceased and there was no swimming response after stimulation with a plastic Pasteur pipette. 


\subsection{In situ bioassays}

In situ bioassays were carried out using a test chamber constructed from a 11 polyethylene terephthalate plastic bottle. The sides and bottom of the bottle were cut out and replaced with $1.0 \mathrm{~mm}$ nylon mesh. The mesh was attached with non-toxic thermal glue (Castro et al., 2003). Five chambers were placed in the field, attached to a pole fixed in the sediment. These structures were placed approximately $2.0 \mathrm{~m}$ from the water's edge and ca. $0.5 \mathrm{~m}$ deep. The organisms used were of the same origin and age as those used in the laboratory tests. Five to seven organisms were placed in each chamber, totalling 25-35 organisms exposed in each bioassay. All fish in a single chamber were placed at the same time, with 1 min intervals between the setup of subsequent chambers. Fish were checked for mortality every $10 \mathrm{~min}$, considering the different exposure times. The bioassays were terminated upon the death of the last organism. The controls consisted of totally closed test chambers which were filled with the same dechlorinated tap water used in the laboratory tests and suspended in the water column.

\subsection{Data analysis}

Median lethal time $\left(\mathrm{LT}_{50}\right.$ : time at which $50 \%$ of the test animals were affected) was determined by Probit Analysis. The paired Student's $t$-test (Zar, 1996) was used to compare the mean values for both bioassays. Differences with $p \leqslant 0.05$ were considered significant. All results are given as means followed by $95 \%$ confidence intervals.

\section{Results and discussion}

Survival in all in situ and laboratory assays control was greater than $90 \%$, thus accomplishing the recommendations from OECD (1992) and ABNT (2002).

Dissolved oxygen concentrations were above 7.0 and $8.5 \mathrm{mg}^{-1}$ for Dunas Lake and control samples, respectively, and therefore did not interfere with the toxicity results.

Mean values and the respective confidence intervals of $\mathrm{pH}$, conductivity and total hardness of the control and Dunas Lake water samples are shown in Table 1. No statistically significant differences in $\mathrm{pH}(t=0.9085, p=0.3801)$, conductivity $(t=1.867, p=0.0847)$ or hardness values ( $t=1.887, p=0.0835$ ) were detected between the samples from Dunas Lake taken in situ and those from laboratory bioassays.

Mean $\mathrm{LT}_{50}$ of the in situ bioassays was $0.72(0.55-0.89)$ $\mathrm{h}$, while in the laboratory bioassays it was $1.61(1.36-1.87)$ h. This difference was highly significant $(t=7.617, p<$ 0.0001 - Fig. 1).

Differences frequently are observed between the responses obtained in laboratory and in situ bioassays (Castro et al., 2003; Moreira-Santos et al., 2004). In situ bioassays, however, reduce uncertainties and errors associated with laboratory conditions (Ireland et al., 1996; Chappie and Burton, 2000) and provide more realistic results (Burton and Nordstrom, 2004). The results of the current study indicate that toxicity was underestimated by laboratory bioassays in comparison with field tests (Tonissi and Espíndola, 2000) due to the differences between the assay conditions (Pereira et al., 2000). This difference illustrates the discrepancy that often exists in ecotoxicological studies, especially due to difficulty in reproducing natural conditions (da Silva et al., 1998). To these authors, although contradictory, this discrepancy is the main motive why new methodologies and strategies had been developed to reduce the uncertainty factors. According to Araújo et al. (submitted for publication), $\mathrm{pH}$ is the main factor responsible for toxicity of the Dunas Lake. It is not likely that transportation and storage of the samples (Castro et al., 2003) have interfered in the water quality in the current study, because no statistical difference was detected between mean $\mathrm{pH}$ values measured in the field and the laboratory (Table 1).

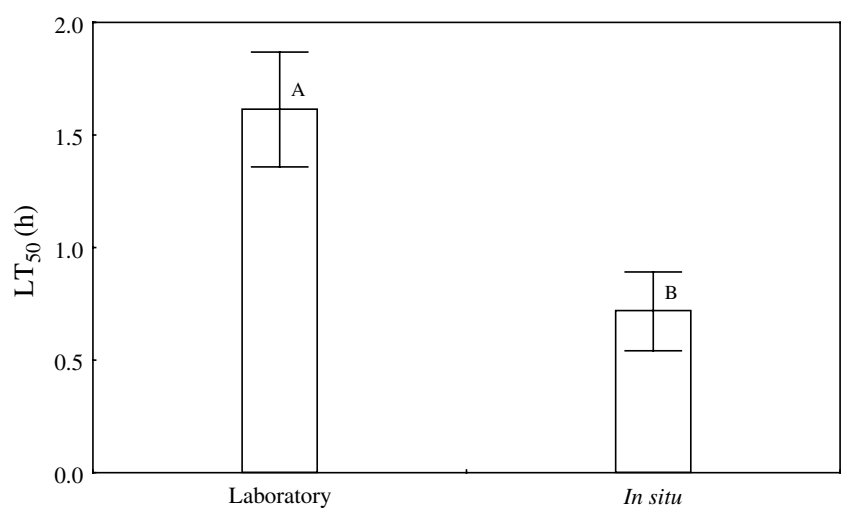

Fig. 1. Mean values and respective $95 \%$ confidence intervals $(n=14)$ of $\mathrm{LT}_{50}$ from laboratory and in situ bioassays with $P$. reticulata exposed to Dunas Lake water samples.

Table 1

Mean values and respective $95 \%$ confidence intervals $(n=14)$ of $\mathrm{pH}$, conductivity and hardness of the control and Dunas Lake water samples from in situ and laboratory bioassays with $P$. reticulata

\begin{tabular}{lccc}
\hline Variable & Samples & & \\
\cline { 2 - 4 } & Control & Dunas Lake (in situ) & Dunas Lake (laboratory) \\
\hline $\mathrm{pH}$ & $7.45(7.14-7.77)$ & $3.12(3.01-3.23)$ & $3.08(3.03-3.13)$ \\
Conductivity $\left(\mu \mathrm{S} \mathrm{cm}^{-1}\right)$ & $371.21(330.56-411.87)$ & $351.43(337.53-365.33)$ & $343.71(329.53-357.85)$ \\
Hardness $\left(\mathrm{mg} \mathrm{CaCO}_{3}{ }^{-1}\right)$ & $114.88(106.66-123.12)$ & $79.29(74.27-84.30)$ & $79.68(74.60-84.77)$ \\
\hline
\end{tabular}


In the current study, in situ bioassays proved to be more sensitive, as they showed a higher toxicity than laboratory results, and are therefore probably more accurate. Generally, in situ exposure provides more accurate results due to the more realistic conditions (Chappie and Burton, 1997; Burton and Nordstrom, 2004; Smolders et al., 2004; Burton et al., 2005). On the other hand, the apparent higher sensitivity observed in the in situ bioassays may be influenced by the transportation and handling of test organisms (Pereira et al., 2000). Consequently, all efforts should be made to minimize these stress factors (Chappie and Burton, 2000), and caution is needed when interpreting bioassays results (Pereira et al., 2000). In general, when organisms are properly transported and handled within acceptability criteria, the effects on the final results will be minimized (Moreira-Santos et al., 2004).

Precision is reflected by the variability of the estimate (Andrew and Mapstone, 1987), and can be demonstrated by the coefficient of variation (CV). In the in situ bioassays, the $\mathrm{CV}$ was $41.09 \%$, while in the laboratory bioassays was $27.16 \%$. Variability in the field is generally significantly higher than in the laboratory (Schulz and Liess, 1999). Accuracy and precision are important factors in establishing the credibility of the results (Dave, 1993; Warren-Hicks et al., 2000). Our in situ bioassays results appeared to be more accurate than laboratory bioassays, since they showed higher sensitivity. In contrast, the field tests were less precise than laboratory bioassays, because variations due to environmental factors in the field are undoubtedly higher than under controlled laboratory conditions.

According to Castro et al. (2003), laboratory bioassays supply only partial information for extrapolation to field conditions, thus they must be interpreted carefully. In spite of being more accurate, in situ bioassays are much more difficult to interpret due to the variations in conditions associated with field exposures (Pereira et al., 2000). Indeed, the use of both bioassay types seeks to evaluate and understand the environmental process more adequately.

Several behavioural changes were observed before immobility and mortality occurred: (i) the fish, on the whole, tended to gather at the surface, motionless, with some respiratory difficulties; (ii) there was some colour change in the abdominal area, which became more whitened; and (iii) there was also a loss of equilibrium, exemplified by spiral swimming behaviour and loss of vertical orientation in the water. In general, these changes were similar to those observed by Polat et al. (2002), Viran et al. (2003) and Yilmaz et al. (2004) in other studies.

\section{Conclusions}

In situ bioassays with $P$. reticulata were demonstrated to be an excellent tool for the biomonitoring of the Dunas Lake, being more sensitive than laboratory bioassays, therefore more accurate, as they reflect more efficiently the conditions of the natural environment. This type of bioassay also presents further advantage in being an easier, low cost methodology.

In spite of showing significant differences in median times to mortality $\left(\mathrm{LT}_{50}\right)$ between in situ and laboratory bioassays, the results do not differ ecologically speaking, since fish are not able to survive in either situation. Moreover, it should also be considered that, in both situations, mortality occurs in a short time when compared to the fish life cycle.

Laboratory bioassays should be continued in the Dunas Lake study, for the purpose of comparing present and previous results, but in situ bioassays should be introduced in the biomonitoring program due to their accuracy and credibility. In addition, an integrated assessment will increase the ecological realism and decrease eventual uncertainties related to understanding and predicting the effects of stressing agents on the biological community.

\section{Acknowledgements}

The authors are grateful to Lyondell Inc. (Brazil) and the Brazilian Research Council (CNPq) for supporting this study (Grant \# 620151/2004-8). C.V.M. Araújo and C.B.A. Chastinet received scholarships from the Brazilian Coordination of Improvement of Personnel of Superior Level (CAPES) and $\mathrm{CNPq}$, respectively. The authors are also thankful to R. Ribeiro (University of Coimbra), A.L. Fonseca (Federal University of Itajubá) and D.H. Smith (Virginia Department of Environmental Quality) for improving the original manuscript.

\section{References}

ABNT - Associação Brasileira de Normas Técnicas. 2002. Água - Ensaio de toxicidade aguda com peixes - Parte I - Sistema estático (NBR 12714). ABNT, Rio de Janeiro.

Andrew, N.L., Mapstone, B.D., 1987. Sampling and the description of spatial pattern in marine ecology. Oceanogr. Mar. Biol. Ann. Rev. 25, 39-90.

APHA. 1998. Standard methods for examination of water and wastewater. 20 Ed. American Public Health Association, Port City Press, Baltimore, Maryland.

Araújo, C.V.M., Cohin-de-Pinho, S.J., Chastinet, C.B.A., Santos, J.S., da Silva, E.M., submitted for publication Discriminating the $\mathrm{pH}$ toxicity to Poecilia reticulata Peters, 1859 in the Dunas Lake (Camaçari, Bahia, Brazil). Ecotoxicol. Environ. Saf.

Boluda, R., Quintanilla, J.F., Bonilla, J.A., Sáez, E., Gamón, M., 2002. Application of the microtox test and pollution indices to the study of water toxicity in the Albufera Natural Park (Valencia, Spain). Chemosphere 46, 355-369.

Burton Jr., G.A., Nordstrom, J.F., 2004. An in situ toxicity identification evaluation method Part I: laboratory validation. Environ. Toxicol. Chem. 23 (12), 2844-2850.

Burton Jr., G.A., Greenberg, M.S., Rowland, C.D., Irvine, C.A., Lavoie, D.R., Brooker, J.A., Moore, L., Raymer, D.F.N., McWilliam, R.A., 2005. In situ exposures using caged organisms: a multi-compartment approach to detect aquatic toxicity and bioaccumulation. Environ. Pollut. 134, 133-144.

Castro, B.B., Guilhermino, L., Ribeiro, R., 2003. In situ bioassay chambers and procedures for assessment of sediment toxicity with Chironomus riparus. Environ. Pollut. 125, 325-335. 
Chappie, D.J., Burton Jr., A.B., 1997. Optimization of in situ bioassay with Hyalella azteca and Chironomus tentans. Environ. Toxicol. Chem. 13 (3), 559-564.

Chappie, D.J., Burton Jr., G.A., 2000. Applications of aquatic and sediment toxicity testing in situ. Soil Sediment. Contam. 9, 219-245.

da Silva, E.M., Soares, A.M.V.M., Sobral, O.M.F., Lopes, I.M.C.A., Correia, J.F.J.S., Marchante, E.M.D.C., Chastinet, C.B.A., Moreno, A.J.M., 1998. Ecotoxicological responses of isolated mitochondrial systems to complex effluents. Are they worthwhile?. Chemosphere 37 2695-2701.

da Silva, E.M., Barros, A.F., Navarro, M.F.T., Mota, M.F.V., Cotsifis, P., Chastinet, C.B.A., 1999a. Rehabilitation following industrial contamination: Jauá Lake, a coastal wetland in Camaçari, Bahia, Brazil. In: Streever, W. (Ed.), An International Perspective on Wetland Rehabilitation. Kluver Academic Press, Netherlands, pp. 197-203.

da Silva, E.M., Navarro, M.F.T., Barros, A.F., Mota, M.F.V., Chastinet, C.B.A., 1999b. The utilisation of Poecilia reticulata as a biomonitor in the environmental recovery of an aquatic ecosystem. Ecotoxicol. Environ. Restor. 2, 51-55.

da Silva, E.M., Navarro, M.F.T., Barros, A.F., Mota, M.F.V., Chastinet, C.B.A., 2000. Metals in the sediments of Jauá Lake (Camaçari, Bahia, Brazil) following an episode of industrial contamination. Aquatic Ecosyst. Health Manage. 3, 509-514.

Dave, G., 1993. Replicability, repeatability, and reproducibility of embryo-larval toxicity tests with fish. In: Soares, A.M.V.M., Calow, P. (Eds.), Progress in Standardization of Aquatic Toxicity Tests. Lewis, Boca Raton, FL, pp. 129-157.

Esteves, F.A., 1998. Fundamentos da Limnologia. 02 Ed. Interciência, Rio de Janeiro, 602p.

Farag, A.M., Woodward, D.F., Little, E.E., 1993. The effects of low pH and elevated aluminum on yellowstone cutthroat trout (Oncorhynchus clarki bouvieri). Environ. Toxicol. Chem. 12, 719-731.

Gomes, D.C., 1994. Poluição de aquífero costeiro de Arembepe-BA por ácido sulfúrico e compostos inorgânicos oriundos da produção de dióxido de titânio. Dissertação de Mestrado. Universidade de São Paulo.

Ireland, D.S., Burton Jr., G.A., Hess, G.G., 1996. In situ toxicity evaluations of turbidity and photoinduction of polycyclic aromatic hydrocarbons. Environ. Toxicol. Chem. 15 (4), 574-581.

Jesus, E.F.R., 1996. A importâncias do estudo das chuvas ácidas no contexto da abordagem climatológica. Sitientibus 14, 143-153.

Kapanen, A., Itävaara, M., 2001. Ecotoxicity tests for compost applications. Ecotoxicol. Environ. Saf. 49, 1-16.

Lewis, M.A., Pittinger, C.A., Davidson, D.H., Ritchie, C.J., 1993. In situ response of natural periphyton to an anionic surfactant and an environmental risk assessment for phytotoxic effects. Environ. Toxicol. Chem. 12, 1803-1812.

Moreira-Santos, M., Soares, A.M.V.M., Ribeiro, R., 2004. An in situ bioassay for freshwater environments with the microalga Pseudokirchneriella subcaptata. Ecotoxicol. Environ. Saf. 59, 164-173.
OECD - Organisation Economic Co-operation and Development. 1992. Guideline for testing of chemicals. Fish Acute Toxicity Test. OECD Guideline for Testing of Chemicals, Paris.

Pereira, A.M.M., Soares, A.M.V.M., Gonçalves, F., Ribeiro, R., 2000. Water-column, sediment, and in situ chronic bioassays with cladocerans. Ecotoxicol. Environ. Saf. 47, 27-38.

Persoone, G., Van de Vel, A., Van Steertegem, M., De Nayer, B., 1989. Predictive value of laboratory tests with aquatic invertebrates: influence of experimental conditions. Aquat. Toxicol. 14, 149-166.

Petersen, G., Kristensen, P., 1998. Bioaccumulation of lipophilic substances in fish early life stage. Environ. Toxicol. Chem. 17, 1385-1395.

Polat, H., Erkoç, F.Ü., Viran, R., Koçak, O., 2002. Investigation of acute toxicity of beta-cypermethrin on guppies Poecilia reticulata. Ecotoxicol. Environ. Saf. 49, 39-44.

Ribeiro, R., Lopes, I., Pereira, A.M.M., Gonçalves, F., Soares, A.M.V.M., 2000. Survival time of Ceriodaphia dubia in acid waters with metal contamination. Bull. Environ. Contam. Toxicol. 64, 130 136.

Schulz, R., Liess, M., 1999. Validity and ecological relevance of an active in situ bioassay using Gammarus pulex and Limnephilus lunatus. Environ. Toxicol. Chem. 18 (10), 2243-2250.

Smolders, R., Bervoets, L., Blust, R., 2004. In situ and laboratory bioassays to evaluate the impact of effluent discharges on receiving aquatic ecosystems. Environ. Pollut. 132, 231-243.

Tonissi, F.B., Espíndola, E.L.G., 2000. Utilização de bioensaios agudo, crônico-parcial e in situ com Danio rerio para avaliação ecotoxicológica do reservatório de Salto Grande (Americana, SP). In: Espíndola, E.L.G., Botta-Paschoal, C.M.R., Rocha, O., Bohrer, M.B.C., OliveiraNeto, A.L. (Eds) Ecotoxicologia: Perspectivas para o século XXI. RiMa, São Carlos, pp. 483-498.

USEPA, 2001. Methods for collection, storage and manipulation of sediments for chemical and toxicological analyses: technical manual. EPA-823-B-01-002. US Environmental Protection Agency, Office of Water, Washington, DC.

Viran, R., Erkoç, F.Ü., Polat, H., Koçak, O., 2003. Investigation of acute toxicity of deltamethrin on guppies (Poecilia reticulata). Ecotoxicol. Environ. Saf. 55, 82-85.

Warren-Hicks, W.J., Parkhurst, B.R., Moore, D.R.J., Scott Teed, R., Baird, R.B., Berger, R., Denton, D.L., Pletl, J.J., 2000. Assessment of whole effluent toxicity test variability: partitioning sources of variability. Environ. Toxicol. Chem. 19 (1), 94-104.

Wiersma, G.B., Rogers, R.C., McFarlane, J.C., Bradley, D.V., 1980. Biological monitoring techniques for assessing exposure. In: Worf, D.L. (Ed.), Biological Monitoring for Environmental Effects. Lexington Books, DC Heathand Company, Lexington, Massachusetts, Toronto, pp. 123-132.

Yilmaz, M., Gül, A., Erbaşli, K., 2004. Acute toxicity of alphacypermethrin to guppy (Poecilia reticulate, Pallas, 1859). Ecotoxicol. Environ. Saf. 56, 381-385.

Zar, J.H., 1996. Biostatistical Analysis, 3rd ed. Prentice-Hall Int, Upper Saddle River, NJ, USA. 